NBER WORKING PAPER SERIES

\title{
THE RELATIONSHIP BETWEEN EXCHANGE RATES AND INFLATION TARGETING REVISITED
}

\author{
Sebastian Edwards \\ Working Paper 12163 \\ http://www.nber.org/papers/w12163 \\ NATIONAL BUREAU OF ECONOMIC RESEARCH \\ 1050 Massachusetts Avenue \\ Cambridge, MA 02138 \\ April 2006
}

This is a revised version of a paper presented at the Banco Central de Chile Annual Research Conference, held in Santiago, Chile in October, 2005. I have benefited from discussions with John Taylor and Ed Leamer. I thank Roberto Alvarez for his help and support. I am grateful to Andrea Tokman and Edi Hochreiter for helpful comments. The views expressed herein are those of the author(s) and do not necessarily reflect the views of the National Bureau of Economic Research.

(C2006 by Sebastian Edwards. All rights reserved. Short sections of text, not to exceed two paragraphs, may be quoted without explicit permission provided that full credit, including $(\odot)$ notice, is given to the source. 
The Relationship Between Exchange Rates and Inflation Targeting Revisited Sebastian Edwards

NBER Working Paper No. 12163

April 2006

JEL No. F-02, F-43

\begin{abstract}
This paper deals with the relationship between inflation targeting and exchange rates. I address three specific issues: first, I analyze the effectiveness of nominal exchange rates as shock absorbers in countries with inflation targeting. This issue is closely related to the magnitude of the "pass-through" coefficient. Second, I investigate whether exchange rate volatility is different in countries with an inflation targeting regime than in countries with alternative monetary policy arrangements. And third, I discuss whether the exchange rate should play a role in determining the monetary policy stance under inflation targeting. An alternative way of posing this question is whether the exchange rate should have an independent role in an open economy Taylor rule.
\end{abstract}

\author{
Sebastian Edwards \\ UCLA Anderson Graduate School of Business \\ 110 Westwood Plaza, Suite C508 \\ Box 951481 \\ Los Angeles, CA 90095-1481 \\ and NBER \\ sebastian.edwards@anderson.ucla.edu
}




\section{Introduction}

For decades the exchange rate was at the center of macroeconomic policy debates in the emerging markets. In many countries the nominal exchange rate was often used as a way of bringing down inflation; in other countries -- mostly in Latin America -- the exchange rate was used as a way of (implicitly) taxing the export sector. ${ }^{1}$ Currency crises were common and were usually the result of acute (real) exchange rate overvaluation. During the 1990s academics and policy makers debated the merits of alternative exchange rate regimes for the emerging economies. Based on credibility-based theories many authors argued that developing and transition countries should have hard peg regimes - preferably currency boards or dollarization. One of the main arguments for favoring rigid exchange rate regimes was that emerging economies exhibited a "fear to float."2 After the currency crashes of the late 1990s and early 2000, however, a growing number of emerging economies moved away from exchange rate rigidity and adopted a combination of flexible exchange rates and "inflation targeting." Because of this move the exchange rate has become less central in economic policy debate in most emerging markets. This, however, does not mean that the exchange rate has disappeared from policy discussions. Indeed, with the adoption of inflation targeting a number of important exchange rate-related questions - many of them new - have emerged. In this paper I address three broad policy issues related to inflation targeting (IT) and exchange rates that have become increasingly important in analyses on monetary policy in emerging countries. ${ }^{3}$

- First, I deal with the effectiveness of the nominal exchange rate as a shock absorber in IT regimes. This issue is related to the extent of the "pass-

\footnotetext{
1 Argentina is, possibly, the best example where, through time, the nominal exchange rate has been used in an effort to achieve alternative policy objectives. For a long time during the 1960s and 1970s the real exchange rate was deliberately kept at an overvalued level, as a way to (implicitly) tax the agriculture sector (Diaz Alejandro, 1970). In the early 1980s the exchange rate was devalued at a slow pre-defined rate as a way to bring down inflation - this was the so-called "tablita" episode. During the 1990s Argentina had a fixed exchange rate and a currency board. For a historical view of Argentina's exchange rate policies see Della Paolera and Taylor (2003).

${ }^{2}$ See Calvo (1999), Calvo and Reinhart (2002).

${ }^{3}$ On inflation targeting see Bernanke et al (2001), Bernanke (2004), Mishkin and Schmidt-Hebbel (2001), Mishkin and Jonas (2003), Mishkin and Savastano (2001), Corbo and Schmidt-Hebbel (2003), and Schmidt-Hebbel and Werner (2002).
} 
through" from the exchange to domestic prices. I argue that much of the literature on pass through has missed the important connection between "pass-through" and exchange rate effectiveness as a shock absorber.

- Second, I analyze whether the adoption of IT has had an impact on exchange rate volatility. Many authors have pointed out that since IT requires (some degree of) exchange rate flexibility, it necessarily results in higher exchange rate volatility. ${ }^{4}$ This, however, is not a very interesting statement. A more useful analysis would separate the effects of IT, on the one hand, and of a more flexible exchange rate regime, on the other, on exchange rate volatility. This is what I do in section III of the paper.

- And third, I discuss whether in an inflation targeting regime the exchange rate should affect the monetary policy rule. I point out that, from an analytical perspective, this is still an unresolved issue. At the policy level, very few IT central banks openly recognize using the exchange rate as a (separate) term in their policy rules (i.e. Taylor rules). However, existing empirical evidence suggests that almost every central bank does take exchange rate behavior into account when undertaken monetary policy. ${ }^{5}$

Much has been written about these three topics. And yet, there continue to be unresolved policy issues surrounding all of them. In this paper I take a new look at these issues, and I argue that recent policy debates have missed some of the finer aspects of these problems. In Sections II and III, on pass-through and volatility, I perform comparative empirical analyses for a group of 7 countries - two advanced and five emerging - that have adopted inflation targeting. ${ }^{6}$ In Section IV, on the other hand, I discuss the possible role of the exchange rate in determining the monetary policy stance in an IT system. Section V is the conclusions.

\footnotetext{
${ }^{4}$ See Mishkin and Savastano (2001) for a discussion on the requirements for an IT regime to work.

5 See the discussion in Section IV.

6 These countries were selected for two reasons: first, I am interested in having countries representing different regions and different stages of development. Second, I need fairly long time series in order to perform the empirical analysis.
} 


\section{The Effectiveness of the Nominal Exchange Rate as a Shock Absorber in Inflation Targeting Regimes: An Analysis of Pass-Through in IT}

\section{Countries}

For many years economists have been concerned with the effectiveness of nominal exchange rate changes as shock absorbers. This issue has been related with the traditional rejection of "structuralists" to devaluations, and with the historical skepticism regarding the benefits of flexible exchange rates. From a policy point of view this issue can be decomposed in three questions: (a) what are the effects of nominal exchange rate changes on the real exchange rate? (b) What are the effects of real exchange rate changes on the external position of a country? And (c) what are the collateral effects of nominal exchange rate changes on balance sheets and aggregate economic activity.

In this section I deal with the first issue - the effects of nominal exchange rate changes on real exchange rates - in inflation targeting regimes. This question is directly related to the issue of the "pass-through" from exchange rates to domestic prices, an issue that have been discussed in great detail in the last few years. Much of the recent literature on pass-through, however, has ignored this "exchange rate effectiveness" question, and has focused on the inflationary effects of exchange rate changes. If the inflationary effects of exchange rate changes are large, the authorities will have to implement monetary and fiscal policies that offset the inflationary consequences of exchange rate changes. Historically, pass-through has tended to be large in emerging countries and, in particular, in countries that experience a currency crises. Borensztein and De Gregorio (1999), for example, used a 41 countries sample and found that after one year $30 \%$ of a nominal devaluation has been passed through to inflation; after two years the pass-through was a very high $60 \%$ on average. They also found that the degree of pass-through was significantly smaller in advanced countries.

A number of recent papers have shown that the degree of pass-through has declined substantially since the 1990s; particularly telling examples are the UK and Sweden after their currency crises in the early 1990s, and Brazil after the 1999 devaluation of the real. In an influential paper Taylor (2000) has argued that this lower pass-through has been the result of a decline in the level and volatility of inflation. According to him, one of the positive consequences of a strong commitment towards 
price stability is that the extent of pass-through declines significantly, and a virtuous circle of sorts develops: lower inflation reduces pass-through, and this, in turn, helps maintain low inflation. Campa and Goldberg (2002) used data on domestic prices of imports for OECD countries to test Taylor's proposition; their results suggest that monetary conditions are only mildly related to the degree of pass-through. More recently, Gagnon and Ihrig (2004) have used a sample of advanced nations to analyze this issue, and have concluded that the decline in the pass-through has been related to changes in monetary policy procedures and, in particular, to the adoption of inflation targeting.

\section{II.1 Two Notions of Pass Through}

Most authors have argued - either implicitly or explicitly - that a decline in the degree of pass-through is a positive development; after all, a lower pass-through will result in a decline in inflationary pressures coming from abroad. A limitation of this inflation-centered view, however, is that it is too simplistic and tends to ignore the role of relative prices, an in particular the fundamental role played by the real exchange rate. ${ }^{7}$

Once relative prices are introduced into the analysis, it is clear that the "passthrough problem" does not only affect inflation; it is also related to the effectiveness of the nominal exchange rate as a shock absorber. In this context, it is important to make a distinction between the pass-through of exchange rate changes into the price of nontradabales and into the domestic price of tradables. While a high pass through for nontradables will reduce the effectiveness of the nominal exchange rate, a high pass through for tradables will enhance its effectiveness.

To illustrate this point, consider the standard definition of the real exchange rate $\rho$ as the (domestic) relative price of tradable to non-tradable goods:

$$
\rho=\frac{P_{T}}{P_{N}},
$$

\footnotetext{
7 Edwards and Levy-Yeyati (2005) analyze the effectiveness of alternative exchange rate regimes to accommodate external shocks. In order for the exchange rate to act as a shock absorber, it is necessary for nominal changes in the nominal exchange rate to be translated into real exchange rate changes. See also Hochreiter and Siklos (2002).
} 
where $P_{T}$ is the domestic price of tradables and $P_{N}$ is the price of nontradables. For the nominal exchange rate to be an effective shock absorber - either under an adjustable or under a flexible exchange rate regime -, a depreciation of the nominal exchange rate $(\mathrm{E})$ will have to generate an increase in $\rho$; if this happens, the change in $\rho$ will help generate an expenditure switching effect. In traditional models this result is assured by three assumptions: (1) the "law of one price" holds for tradables; ${ }^{8}(2) P_{N}$ is the result of the clearing conditions in the nontradables market; and (3) economic authorities pursue 'tight" monetary and fiscal policies and nominal wages do not adjust automatically as a result of the nominal depreciation.. The first two assumptions are summarized in equations (2a) and (2b):

$$
\begin{aligned}
& P_{T}=E P_{T}^{*} \\
& N^{S}\left(\frac{W}{P_{N}}\right)=N^{D}(\rho, A) .
\end{aligned}
$$

Where $E$ is the nominal exchange rate (an increase in $\mathrm{E}$ is a nominal depreciation), $P_{T}^{*}$ is the international price of tradables; $N^{S}, N^{D}, W$ and $A$ are the supply and demand for nontradables, nominal wages and absorption. Absorption, in turn, is affected by fiscal policy and monetary policy; both expansive fiscal and monetary will result in a higher $A$. In this setting, and assuming that the international price of tradables does not change:

$$
\frac{d \log \rho}{d \log E}=1-\left(\alpha_{1}+\alpha_{2} \frac{d \log W}{d \log E}+\alpha_{3} \frac{d \log A}{d \log E}\right) .
$$

Where $\alpha_{1}=\frac{\eta}{\eta-\varepsilon}, \alpha_{2}=\frac{-\varepsilon}{\eta-\varepsilon}, \alpha_{3}=\frac{\phi}{\eta-\varepsilon}$, and $\eta \geq 0, \varepsilon \leq 0, \phi \geq 0$ are elasticities.

According to the traditional monetary model, the pass-through from the exchange rate to the domestic price of tradables will be unitary, and the pass-through to the domestic price of nontradables will depend on wage rate behavior and absorption policies. Under the

\footnotetext{
${ }^{8}$ This assumption is often referred to as "producer-currency pricing."
} 
classical case, $d \log W=d \log A=0$, and the pass-through to $P_{N}$ will be equal to $0<$ $\left(1-\alpha_{1}\right) \leq 1$. In this case, a nominal depreciation will result in a real exchange rate depreciation -- that is, $\frac{d \log \rho}{d \log E}>0$--, and the nominal exchange rate will play a role as a shock absorber.

There is no need, however, for the assumptions of the traditional monetarist model to hold in the real world. Indeed, it is possible to show that if there is an automatic backward looking wage indexation mechanism, the pass-through to the price of nontradables will be equal to one, and that $\frac{d \log \rho}{d \log E}=0$. Moreover, as shown in Edwards (1998), if the monetary authorities have low credibility and labor unions expect inflationary pressures in the future, $\frac{d \log W}{d \log E}>0$, the effectiveness of the nominal exchange rate as a shock absorber will decline.

A number of analysts have questioned the validity of the law of one price for tradables (equation 2a), even in small economies. If export firms have some monopolistic power, they will set prices in a way that maximize profits. In this case, they will "price to market" and will not alter their domestic prices in a particular market in proportion to exchange rate changes (see Atkenson and Burstein 2005, for a recent survey and results). The easiest way to visualize this is to consider the optimal pricing strategy for a monopoly operating in country $j$. In this case, instead of equation (2a) for the domestic price of tradables, we have (2c):

$$
P_{T}^{j}=\mu M C^{j}
$$

$\mu$ is the markup; $M C$ is the marginal cost of operating in country $\mathrm{j}$ (in domestic currency) and will depend on production costs, the cost of transportation and distribution costs. The markup, will depend on the price elasticity of demand for $T$ in country $\mathrm{j}(\vartheta$ ) and is given by: $\mu=\frac{\vartheta}{1+\vartheta}$, where $\vartheta<0$. The elasticity, in turn, will depend on a number of variables, including income growth and the degree of price instability in the economy. 
It is clear from (2c) that under most circumstances a change in the nominal exchange rate will not be translated into a one-to-one change in the domestic price of tradables. This is for two reasons: first, $M C$ needs not remain constant when $E$ changes. And second, the mark-up will not remain unchanged when the exchange rate depreciates; indeed, it is likely to decline. ${ }^{9}$ This means that the magnitude of the pass-through from exchange rate to the price of tradables is likely to be smaller than one. In the extreme case when the pass-through into importable goods is zero we say that the market is characterized by “local currency pricing."

Although the framework developed here could be made more complex - by assuming that nontradables use tradable inputs, for example --, the main points would still be valid. In particular, once the role of the real exchange rate is explicitly introduced into the analysis, it is important to distinguish between two notions of exchange rate passthrough: pass-through into nontradables, and pass-through into tradables. In this context, and from a policy perspective, a desirable situation is one where pass-through coefficients for tradables and nontradables are low and different, with the pass through for tradable goods being higher than that for nontradables.

In this section I use data from seven countries that have adopted inflation targeting to investigate whether the magnitude of the pass-through has been affected by the adoption of this monetary policy; see Table 1 for a list of countries and the date when IT was enacted. One of the main objectives of this analysis is to investigate whether the adoption of IT has affected the effectiveness of nominal exchange rates as shock absorbers. As pointed out above, this would be the case if the pass-through from exchange rates to nontradable prices has declined and/or the pass-through to tradables goods has increased (or, at least, has not declined).

\section{II.2 Empirical Model}

An empirical analysis of the pass-through that focuses on inflation and the real exchange rate would consider the way in which changes in nominal exchange rates affect the domestic prices of nontradable and tradable goods. In most countries, however, there are important data limitations; in particular, very few countries have data on nontradables prices. Data limitations are more severe in emerging countries, where long series of

\footnotetext{
${ }^{9}$ This is the case under many forms of the demand curve.
} 
domestic prices of importables are rarely available. ${ }^{10}$ For this reason, in the empirical analysis that follows I have used the CPI index as a proxy for the domestic price of nontradables $\left(P_{N}\right)$ and the PPI as a proxy for the domestic price of tradables $\left(P_{T}\right)$. This means that I am using the ratio $\left(\frac{P P I}{C P I}\right)$ as a proxy for the real exchange rate in equation (1). As it turns out, and as is illustrated in Figure 1 for the case of Chile, in many countries this is a fairly good proxy for the (effective) real exchange rate.

Most empirical studies on pass-through have estimated variants of the following equation (Campa and Goldberg 2002; Gagnon and Ihrig 2004):

$$
\Delta \log P_{t}=\beta_{0}+\beta_{1} \Delta \log E_{t}+\sum \beta_{2 i} x_{i t}+\beta_{3} \Delta \log P_{t}^{*}+\beta_{4} \Delta \log P_{t-1}+\omega_{t} .
$$

Where $P_{t}$ is a price index -- either of importables, tradables or nontradables --, $E$ is the nominal exchange rate, $P *$ is the an index of foreign prices, the $\beta s$ are parameters to be estimated, the $x_{j} s$ are other controls expected to capture changes in the markup, and $\omega_{j}$ is an error term with standard characteristics. The short run pass-through is given by $\beta_{1}$ and the long term pass-through is $\frac{\beta_{1}}{\left(1-\beta_{4}\right)} \cdot{ }^{11}$ Many analysts have imposed the constraint $\beta_{1}=\beta_{3}$. In this paper, however, I consider the more general case, and I allow for different coefficients for the nominal exchange rate and international prices. ${ }^{12}$

From an empirical point of view the question of interest is whether the coefficients $\beta_{1}$ and $\beta_{4}$ have experienced a structural change at (approximately) the time of the adoption of inflation targeting. I investigate this by adding two interactive terms to equation (4). The equation that I actually estimated is:

\footnotetext{
${ }^{10}$ In the IFS, unit import prices for industrialized countries are expressed in domestic currency. However, for most emerging countries they are expressed in US dollars.

${ }^{11}$ Campa and Goldberg (2002) used the sum of four lagged coefficients of the change in the exchange rate to compute the long run pass-through. The distributed-lags approach used by Campa and Goldberg is also followed by most other authors.

${ }^{12}$ Some studies, such as Gagnon and Ihring (2004), have analyzed how different monetary regimes have affected the extent of pass-through.
} 
(4a)

$\Delta \log P_{j t}=\beta_{0}+\beta_{1} \Delta \log E_{t}+\sum \beta_{2 i} x_{i}+\beta_{3} \Delta \log P^{*}+\beta_{4} \Delta \log P_{t-1}+\beta_{5} \Delta \log E_{t} \times D I T$ $+\beta_{6} \Delta \log P_{t-1} \times D I T+\omega_{t}$

Where DIT is a dummy variable that takes the value of one at (approximately) the time IT is adopted, and zero otherwise. The short term pass-through in the post-IT period is $\beta_{1}+\beta_{5}$. Notice that, in contrast with other studies, in (4a) I allow the coefficient of lagged $\Delta \log P$ during the post-IT period to be different from the pre-IT coefficient. This is important for two reasons: first, it allows investigating whether, as argued by Taylor (2000), a more inflationary-focused policy reduces inflationary inertia. Second, it provides an alternative channel through which the long run pass-through may decline. Indeed, since the long run pass-through in the post-IT period is $\left(\frac{\beta_{1}+\beta_{5}}{1-\left(\beta_{4}+\beta_{6}\right)}\right)$, it may be lower than the pre-IT coefficient either because $\beta_{5}$ or $\beta_{6}$ are significantly negative in equation (4a).

In spite of its simplicity, the estimation of equations of the type of (4a) presents several challenges. The most important has to do with potential endogeneity problems. Indeed, it is possible that $\Delta \log E$ in equation (4a) is not exogenous, and is correlated with the error term. In principle, there are several ways to deal with this issue; none of them, however, is particular satisfactory from a practical point of view. First, equation (4a) could be estimated using simultaneous equations methods, such as two stage least squares or generalized method of moments. The problem is that, as is well known, in the vast majority of countries with floating exchange rates it is very difficult to find good instruments for $\Delta \log E$; most exogenous variables are not highly correlated with changes in the nominal exchange rate. ${ }^{13}$ Second, structural VARs could be estimated. However, identification conditions require making assumptions about the timing of the effects of exchange rate on prices that are not particularly convincing. For these reasons, most recent studies on pass through, including Campa and Goldberg (2002) and Gagnon and Ihrig (2004) have relied on least squares methods. An additional challenge in the

\footnotetext{
${ }^{13}$ This difficulty was first pointed out by Meese and Rogoff (1983).
} 
estimation of (4a) is that many countries don't have data on the (possible) determinant of the markup, or additional controls $x$ in equation (4a).

\section{II.3 Data and Empirical Results}

In the estimation of equation (4a) I use quarterly data for the period 1985-2005 for seven countries - two advanced and five emerging - that have adopted inflation targeting at some point during the last 15 years (see Table 1). ${ }^{14}$ Some of these countries - Chile is the premier example - adopted IT in an evolutionary fashion. For this reason, in Table 1 I provide two dates for the adoption of IT in Chile: 1991, when an inflation target range was first announced, and 1994 when a specific inflation rate was adopted as a target . ${ }^{15}$ Unless I indicate otherwise, the results reported in this section were obtained when the mid 1994 date was used as the launching date of IT in Chile. When the alternative 1991date was used, the results obtained were similar.

For each country I estimated two equations: one for the rate of change of the CPI (which, as mentioned, is a proxy for nontradables inflation), and one for the rate of change of the PPI (a proxy for domestic tradables inflation). All data are expressed as quarterly percentage changes. The exchange rate is the effective (multilateral) exchange rate, defined as the domestic price of a basket of currencies. Thus, an increase in $\mathrm{E}$ is a (multilateral) nominal depreciation. ${ }^{16}$ To the extent that it takes some time for a new policy regime to be understood by the public, we would expect that the structural change in the pass-through coefficients would not be instantaneous; it is likely to take place some quarters after the new policy is adopted. In the estimation of (4a) I considered alternative lags for DIT; most of the results reported in Table 2 are for four lags. The rate of change of the US producer price index was used as a proxy for world inflation. In the basic results reported in Table 2, I follow Gagnon and Ihrig (2004) and I do not include additional controls $x$. See, however, the discussion below.

Since, for each country, the errors in the CPI and PPI equations are likely to be correlated, I estimated the two equations for each country simultaneously, using Zellner's

\footnotetext{
${ }^{14}$ In some countries the time period was slightly shorter.

15 Alternatively one could use March 2000, when a Monetary Report was first published, as the relevant date.

${ }^{16}$ For the majority of countries the multilateral effective exchange rate was taken from the IFS. For those countries for which the IFS does not provide the effective rate, I constructed a multilateral exchange rate index.
} 
seemingly unrelated regressions (SURE) procedure. ${ }^{17}$ The results obtained are presented in Table 2. In Table 3, on the other hand, I present a summary of the pass-through coefficients in the pre-inflation targeting and post-inflation targeting periods. The main results obtained may be summarized as follows:

- In all countries the pre-IT short term pass-through coefficient in the CPI equation is positive. It is significantly so in six out of the seven countries; the only exception is Canada whose coefficient is positive but not significant. ${ }^{18}$ However, the estimated coefficients show a significant degree of variability across countries. The short-run, pre-IT pass-through coefficient into nontradable prices (CPI) ranges from a low of 0.020 in Korea, to a very high 0.719 in Brazil. A simple inspection at these estimates suggests that, historically, the CPI pass-through coefficient has been much higher in countries with a tradition of high and chronic inflation (e.g. Brazil), than in countries with traditional price stability (e.g. Korea).

- Also, in six out of the seven countries the short term pass-through coefficient in the PPI (or tradables) equation is significantly positive. There is also a significant variability across countries.

- For the pre-IT period, the point estimate of the short term pass-through coefficient is higher for tradables (PPI) than for nontradables (CPI) in all countries.

- In most countries, and during the pre-IT period, the long-run point estimate for the PPI pass-through is higher than for the CPI pass-through.

- In every case, the estimated coefficient of $(d \log E \times D I T)$ is negative. It is significantly so in the majority of cases. This indicates that the short run pass-through has declined in every country in the sample in the postIT period. Moreover, in most cases the decline has been larger in the CPI (or nontradable) equation than in the PPI equation, indicating that there

\footnotetext{
17 In all equations I also included a time trend and, in the case of Brazil, two dummy variables for the 1989 and 1999 currency crises.

${ }_{18}$ In the analysis that follows I consider as "significant" coefficients with a p-value of $20 \%$ or lower. In the majority of cases, however, the p-values are smaller than $5 \%$.
} 
has been an increase in the short run effectiveness of the nominal exchange rate.

- The decline in the short run CPI pass-through in the post-IT period has been particularly dramatic in the case of Brazil, where the short run coefficient declined from 0.719 to 0.056 . Other cases of major reduction in the pass-through coefficient are Chile, Israel and Mexico. At the other extreme, the change in the degree of CPI (or nontradable) pass-through in Korea is not statistically significant; in this country the CPI pass-through was already very low (0.020).

- The estimates in Table 2 show that in the pre-IT period inflation was characterized by a considerable degree of inertia in most countries measured by the coefficient of lagged $\Delta \log P$. Notice, however, that in most cases, inertia was higher for CPI (or nontradable) inflation than for PPI (or tradables) inflation.

- The estimated coefficients of $\left(\Delta \log P_{-1} \times D I T\right)$ are negative in the vast majority of the countries - the exceptions are Brazil for both definitions of inflation, and Israel for CPI. The estimated coefficient for $\left(\Delta \log P_{-1} \times D I T\right)$ is negative and statistically significant for Australia (CPI), Canada (CPI), and Mexico (CPI and PPI), indicating that in those countries inflationary inertia has significantly declined in the post-IT period.

- The post-IT long run pass-through depends both on the behavior of $\left(\Delta \log P_{-1} \times D I T\right)$ and $(\log E \times D I T)$. As Table 3 shows, for the majority of countries in the sample the long run pass through coefficient has declined in the post-IT period. This is the case both for the CPI (or nontradable) and for the PPI (or tradable) pass-through coefficients.

An interesting question is whether the differences in the pass-through coefficients for the CPI (nontradable) and PPI (tradable) equations reported in Tables 2 and 3 are statistically significant. In order to address this issue I computed Wald $\chi^{2}$ statistics to 
test for cross equation restrictions. The results obtained are reported in Table 4 (p-values in parentheses). The test statistics are $\chi^{2}$ with one degree of freedom, and the null hypothesis is that the pass-through coefficients in the CPI and PPI equations are equal in each country. As may be seen, the null hypothesis is rejected at conventional levels in 4 of the seven countries. ${ }^{19}$ A particularly interesting case is that of Brazil, where the null hypothesis was rejected both in the short and long run in the pre-IT period, and is only rejected in the short run in the post-IT period. As a way of gaining further insights, I also tested the joint hypothesis that the short and long run pass-through coefficients were equal in both the pre and post-IT periods. The results - available on request - indicate that the null hypothesis is rejected for Brazil, Canada and Mexico.

In the estimates reported in Table 2 I included a small number of controls. In order to check for the robustness of the results - and, in particular, to check for possible omitted variables bias - I also estimated equation (4a) including the following controls: (a) deviations of GDP from a stochastic trend, lagged one or two periods (In some regressions this variable was also interacted with the nominal depreciation); (b) deviations of US GSP, lagged one and two periods; (c) the change in the degree of volatility of inflation, lagged one or two periods. (In some regressions this variable was also interacted with the nominal depreciation); and (d) a time trend. The results obtained are very similar to those presented in Table 2 and confirm that in most countries there have been breakpoints in the short run pass-through, the degree of inertia and the long ruin pass-through coefficient. ${ }^{20}$

\section{II.4 Further Results and Comments on Chile's Experience}

Chile has been a pioneering in the implementation of inflation targeting in emerging countries. What makes this case particularly interesting is that for decades Chile had a high and chronic inflation. Starting in the 1940s inflation increased significantly and became a major political and economic problem; until the 1990s repeated efforts to quell it proved to be unsuccessful (Meller 1996). In his celebrated work on inflationary inertia, Pazos (1972) referred to Chile as the premier case of an economy where inflation tended to perpetuate itself. Numerous scholars have analyzed

\footnotetext{
19 Although in most of them the rejection is not across all time-runs and time periods.

20 Results available on request.
} 
the historical behavior of inflation in Chile, and have concluded that fiscal largesse, low Central Bank credibility, and widespread indexation practices (both for wages and the nominal exchange rate) were behind Chile's historical high rates of inflation. In the 1990's, however, there were important changes in Chile's monetary policy: the Central bank was granted independence and it formally adopted an inflation targeting approach (Corbo 1998, Schmidt-Hebbel and Tapia (2002), and Morandé (2002)). Since then inflation has declined significantly. During the last few years it has not been significantly different from world inflation.

The results presented in Tables 2 and 3 of this paper tend to confirm this story: after the adoption of inflation targeting in the early 1990s Chile experienced a decline in the degree of pass-through, both in the case of CPI inflation as well as PPI inflation (Seealso De Gregorio and Tokman, 2004). In this section I provide additional results on Chile's case that provide further light on the relation between inflation and exchange rates. In Table 5 I present new estimates for equation (4a) for CPI (or nontradable) inflation and CPI (or tradable) inflation using three stages least squares, which deals with the potential endogeneity of exchange rate changes. ${ }^{21}$ As may be seen, although the point estimates are somewhat different, the overall results tend to confirm the conclusions reached above. Generally speaking, the 3SLS estimations show that the degree of both CPI and PPI pass-through has declined in the post-IT period. Interestingly, and in contrast with the cases of Australia, Canada and Mexico, there is no evidence of a decline of the degree of inflationary inertia in Chile in the post-IT period. Moreover, in Chile the level of inertia is similar for CPI and PPI inflation. From a comparative perspective, however, inflationary inertia in Chile is not higher than in countries with a long tradition of price stability, such as Australia and Canada (See Table 2).

\section{Inflation Targeting and Exchange Rate Volatility: Some Empirical Tests}

As a number of authors have pointed out, a floating exchange rate system is a requirement for a well functioning inflation targeting regime (Mishkin and Savastano

\footnotetext{
${ }^{21}$ The following instruments were used: lagged first-difference in the US CPI, commodity price index, and first-difference of the US PPI.
} 
2001). ${ }^{22}$ The reason for this is that in a world of capital mobility, independent monetary policy cannot coexist with a pegged exchange rate regime - this is the so-called "Impossibility of the Holy Trinity." This connection between inflation targeting and floating exchange rates has led some analysts to argue that one of the costs of IT is the increase in exchange rate volatility. In a recent paper, De Gregorio, Tokman and Valdés (2005) discuss this issue in the Chilean context, and show that in Chile (nominal) exchange rate volatility has not been higher than in other countries with floating exchange rates.

The way in which the adoption of IT affects exchange rate volatility is an important policy issue. Yet, it is one that has not been dealt with appropriately in recent debates. Indeed, many analysts have compared exchange rate volatility under IT with volatility under a pegged or administered exchange rate regime. This is not an adequate comparison. From a policy evaluation perspective it is important to separate the issue of the selection of the exchange rate regime with the adoption of IT. The correct question is whether the adoption of IT increases exchange rate volatility, controlling for the exchange rate regime. Moreover, most volatility analyses have been based on comparisons of unconditional volatility measures across countries, or across time for the same country.

There are several possible ways of addressing these issues. First, one can analyze whether the adoption of IT affects conditional exchange rate volatility in countries that have had a floating exchange rate for a prolonged period of time, such as Australia and Canada. Second, regressions that control for the exchange rate regime can be estimated. In this section I use both of these approaches and monthly data to analyze this issue. The analysis focuses on the seven countries in Table 1. From a conceptual perspective, once one conditions for the exchange rate regime, it is possible to determine whether IT, by itself, results in an increase in exchange rate volatility. For example, in the cases of Australia and Canada - two countries with a long tradition with floating rates -- a comparison of conditional volatility before and after the implementation of IT will provide information on the effects of the new policy regime on exchange rate behavior.

\footnotetext{
22 There is no need, however, for the authorities to abstain completely from intervention in the foreign exchange market. See the discussion in Section IV of this paper.
} 


\section{III.1 The Data and the Empirical Model}

In Figure 2 I present data on exchange rate volatility, measured as the monthly difference in the log of the nominal effective exchange rate for the countries in my sample for 1988:01-2005:01. These figures capture clearly the degree of instability including the crises -- faced by some of the countries in the sample during the period under study. This figure also shows that in most of the countries instability has experienced important changes.

The changing degree of exchange rate volatility displayed in Figure 2 suggests that, during this period, exchange rate volatility can be explained by models in the generalized autoregressive conditionally heteroskedastic (GARCH) tradition. Most GARCH-based empirical work on exchange rate volatility has tended to ignore, both in the mean and conditional variance equations, the potential role of alternative monetary regimes. Consider the following GARCH model of nominal exchange rates in a particular country:

$$
\begin{aligned}
& \Delta \log E_{t}=\theta+\sum \phi_{j} z_{t-j}+\psi_{t} \\
& \sigma_{t}^{2}=\alpha_{1}+\alpha_{2} \psi_{t-1}+\sum \gamma_{i} \sigma_{t-i}^{2}+\sum \delta_{i} y_{i}
\end{aligned}
$$

Where, as before, $\mathrm{E}$ is the nominal effective exchange rate; the $z^{\prime} s$ are variables that affect changes in the exchange rate, and may include lagged values of $\Delta \log E$, as well as other domestic or international variables; $\psi_{t}$ are innovations to exchange rate changes, with zero mean and conditional variance $\sigma_{t}^{2}$. The $y_{t}$, in equation (6), are variables, other than past squared innovations or lagged forecast variance, that help explain exchange rate volatility.

In this section I report results obtained from the estimation of models based on equations (5) and (6) using monthly data for the countries in Table 1. The time period is 1988:01 through 2005:01, with the exception of Brazil where I analyze the period 1994:06-2005:01. ${ }^{23}$ My main interest is to investigate whether the adoption of an IT

\footnotetext{
23 Approximately in mid-1994, when the real plan was adopted, inflation in Brazil experienced a structural break.
} 
operating procedure for monetary policy has affected exchange rate volatility. In addition, I am interested in understanding whether the adoption of a floating exchange rate regime had an effect on volatility. For this reason, I included two dummy variables as $y_{t}$ in the conditional variance equation (6): DIT, which as before takes the value of one if the country has implemented an IT regime, and FLOAT, which takes the value of one if the country has a floating exchange rate regime. In creating the variable FLOAT I used information from a number of sources, including Levy-Yeyati and Sturzenegger (2003), Reinhart and Rogoff (2004) and the IMF. In the means equation (5) I also included a time trend and, for the cases of Mexico and Korea dummy variables for their major currency crises. ${ }^{24}$

\section{III.2 Results}

In the first step of the analysis I estimated, by ordinary least squares, a number of versions of equation (5) for the seven countries in the sample. ${ }^{25}$ The analysis of the residuals clearly showed the presence of conditional heteroskedasticity. Engle's LM test rejected the null hypothesis of absence of ARCH for every country. In the second step I identified the order of the GARCH process for each of the countries, and I verified stability. Finally, I estimated the system (5) and (6); in all cases the dummy variables for inflation targeting ( DIT ) and for floating regime ( FLOAT) were lagged one period; the results, however, are not affected in a significant way when alternative lag structures are used (including no lags). If the adoption of inflation targeting has indeed resulted in increased nominal effective exchange rate instability, as some critics have argued, the estimated coefficient of DIT would be significantly positive. If floating rates increase exchange rate volatility, as one would expect under most circumstances, the estimated coefficient of FLOAT would be significantly positive. In the estimation of the conditional variance equations for Australia and Canada I did not include the FLOAT variable. The reason for this is that both of these countries have had a floating regime since the mid 1970s.

\footnotetext{
24 In some of the estimates I also included in the means equation the floating regime dummy. Its inclusion does not affect the results, however.

${ }^{25}$ As is customary, a preliminary step consists of analyzing stationarity. I used both country-specific and panel techniques.
} 
The results obtained are in Table 6. I have only reported the order of the GARCH process, and the estimated coefficients of DIT and FLOAT. The main results may be summarized as follows:

- The estimated coefficient of the inflation targeting dummy DIT is positive and very small in three of the countries - Australia, Canada, and Korea. However, in none of these cases it is significantly different from zero. This indicates that (at least in this sample) there is no evidence that the adoption of IT increases nominal multilateral exchange rate volatility.

- The estimated coefficient of the inflation targeting dummy DIT is significantly negative in three of the countries in the sample-Brazil, Chile (for both equations), and Israel -, and negative (but not significant) in Mexico. In the case of Chile, the degree of significance of DIT is higher (in absolute terms) when 1994 is considered as the beginning of the IT period. Interestingly, when the FLOAT variable is excluded, the coefficient of DIT becomes positive (but insignificant) in the conditional variance equations for Chile and Brazil. These results suggest that, after controlling for the exchange rate regime, the adoption of IT has tended to reduce conditional volatility in some countries. The most likely reason for this is that IT is a transparent and predictable monetary framework that tends to reduce unexpected shocks or "news."

- The estimated coefficient of the FLOAT variable is positive in the five equations where it was included. Moreover, it is significantly positive in three of the five equations - for Brazil, Chile, and Israel.

The results reported in Table 6 are for standard GARCH models. In this setting the nominal exchange rate reacts in the same way to positive and negative shocks. However, as a number of authors have argued, it is possible that the nominal exchange rate reacts in an asymmetric fashion to positive and negative shocks. In order to analyze whether this possibility would affect the main results discussed above I estimated a series of TGARCH and EGARCH models for the seven countries in the sample. Although there is some evidence of asymmetric responses, the main conclusions on the coefficients 
of DIT and FLOAT discussed above still hold: there is no evidence that, once one controls for exchange rate regime, the volatility of nominal (multilateral) exchange rates increased with the adoption of IT.

The results presented above are for nominal multilateral exchange rates. An interesting question is whether the adoption of IT has affected real effective exchange rate volatility. In order to analyze this issue I estimated equations of the type of (5) and (6) for the four countries with data on real effective exchange rates at the monthly frequency - Australia, Canada, Chile and Israel. The results obtained are presented in Table 7. As may be seen, they tend to confirm those obtained for nominal multilateral exchange rate volatility. There is no evidence that the adoption of IT has increased real effective exchange rate volatility. In fact, there is some evidence that the opposite has happened in Chile and Israel; in both of these countries the coefficient of DIT is negative, with a Z-statistic in excess (in absolute terms) of 1.2. As in Table 6, these estimates suggest that the adoption of a floating regime increased RER volatility: the estimated coefficients of the FLOAT dummy are significantly positive.

\section{III.3 Extensions for the Case of Chile}

The results reported above span a period where most - but not all - of the countries in the sample experienced important changes in their exchange rate regime. Chile is a case in point. ${ }^{26}$ During this period the country went from having an exchange rate band of varying width to having a flexible exchange rate. It may be argued, thus, that the extent of exchange rate volatility during the band period was limited by the existence of the band itself, even if the actual exchange rate never hit the bands. If this is the case, the results for the emerging countries - but not for Australia or Canada - in Table 6 maybe misleading. In order to deal with this issue in this section I use data on Chile's shadow nominal exchange rate - or exchange rate that would have prevailed in the absence of the bands - to analyze exchange rate volatility in the period 1991-2004. The data on the shadow exchange rate were taken from Edwards and Rigobon (2005). This shadow rate was computed using an iterative procedure based on the behavior of the actual rate, the bands and the fundamentals. Figure 3 presents the evolution of the

\footnotetext{
${ }^{26}$ This also applies to Mexico and Israel. Mexico had a band until late 1994; Israel had a widening crawling band into the 2000s. Korea had a managed exchange rate until 1998; Brazil had a managed rate until 1999.
} 
monthly change of the nominal observed and nominal shadow exchange rate for the Chilean peso relative to the U.S. dollar

The estimation of the conditional variance equation for the shadow exchange rate yielded the following results: the point estimate for the inflation targeting dummy $D I T$ was $-2.36 \mathrm{E}-05$, with a $\mathrm{z}$-statistic of -0.406 . The point estimate for the floating exchange rate dummy FLOAT was 0.00004 , with a $\mathrm{z}$-statistic of $1.62 .^{27}$ These results, then, confirm those reported in the preceding subsection. Even when a shadow exchange rate is used, there is no evidence suggesting that the adoption of IT increased nominal exchange rate volatility; there is, on the other hand, some evidence indicating that the move from a band to a floating regime did have a small (positive effect) on volatility.

\section{Central Bank Policy and the Exchange Rate under an IT Policy Regime}

Should inflation targeting central banks intervene in the foreign exchange market? And if so, how should this intervention take place? Should it be sterilized intervention, where the resulting changes in monetary aggregates are sterilized through operations involving domestic securities? Or should it be non-sterilized intervention, where monetary aggregates are affected $?^{28}$ These are complex questions that have moved to the center of the policy debate in many IT countries, especially in Latin America. In this section I discuss the issue of whether IT central banks should explicitly consider the exchange rate in their monetary rule. ${ }^{29}$ This question is related to a number of important (and controversial) policy issues, including the costs of (real) exchange rate misalignment and "fear of floating.,"30

\footnotetext{
27 In this estimation the $D I T_{1994}$ dummy was used.

${ }^{28}$ Questions do not end here, however. Here are some additional ones: If intervention is sterilized, what type of domestic securities should be used in the sterilization? Should the purchases/sales of forex be done in the spot or in the forward market?

29 It is not my intention to provide a comprehensive survey on the topic of central bank intervention. The literature is voluminous country-specific, and continues to grow every day; interested readers are directed to, among others, Dominguez and Frankel (1993), Taylor (2004), Kearns and Rigobon (2005), Neely (2001), Sarno and Taylor (2001). For an excellent analysis of different central bank policies, including Chile's case, see Tapia and Tokman (2004).

30 On fear of floating see Calvo and Reinhart (2002).
} 


\section{IV.2 The Issues}

From a technical point of view the discussion of the relation between central bank policy and the exchange rate may be framed in terms of the form of the Taylor rule in a small open economy. Taylor himself has posed the problem as follows

"How should the instruments of monetary policy (the interest rate or a monetary aggregate) react to the exchange rate?" (Taylor, 2001, p. 263. Emphasis added)

In order to address this question more formally, consider the following equation: ${ }^{31}$

$$
i_{t}=f \pi_{t}+g y_{t}+h_{0} e_{t}+h_{1} e_{t-1}
$$

Where $i_{t}$ is the short term interest rate used by the central bank as a policy tool, $\pi_{t}$ is the deviation of the rate of inflation from its target level - possibly zero --, $y_{t}$ is the deviation of real GDP from potential real GDP (often called the output gap), and $\mathrm{e}_{\mathrm{t}}$ is the log of the real exchange rate in year $\mathrm{t}^{32} f$ and $g$ are the traditional Taylor rule coefficients; $h_{0}$ and $h_{1}$ are the coefficients of the current and lagged log of the real exchange rates in the expanded Taylor rule, and are the main interest of this discussion. If $h_{0}=h_{1}=0$ exchange rate developments should not be incorporated in the policy rule, and the Taylor rule reverts to its traditional form.

It is conceivable, in principle, that in a small open economy the optimal monetary policy rule - that is the policy that maximizes the authorities' objective function - is one where both $h_{0}$ and $h_{1}$ are different from zero. Interestingly, if $h_{0}>0$ and $h_{0}=-h_{1}$, then the rule implies that monetary policy should react to changes in the (real) exchange rate. Notice that the formulation in equation (7) does not imply, even when $h_{0}$ and $h_{1}$ are different from zero, that the monetary authorities should defend a certain level of the exchange rate. If the optimal policy calls for intervention - that is for $h_{0}$ and $h_{1}$ different

31 This is the precise equation presented by Taylor in his discussion on the subject.

32 In this formulation an increase in e denotes a real exchange rate appreciation. 
than zero --, and if the monetary authorities do follow this policy, a casual observer may conclude that the country in question is subject to "fear of floating." This, however, would be an incorrect inference, as the country in question would be practicing "optimal flotation."

In order to answer fully this question it is necessary to specify the policy maker's objective (or loss) function, and the model that best captures the functioning of the economy. Most authors assume that the goal of policy makers is to minimize a loss function that combines deviations of GDP (or GDP growth) from trend and deviations of inflation from its target. ${ }^{33}$

$$
L=\left(\pi_{t}-\tilde{\pi}\right)^{2}+\lambda\left(y_{t}-\tilde{y}\right)^{2} \text {, and } \lambda>0 .
$$

In equation (8) $\hat{\pi}$ and $\hat{y}$ are the inflation target and potential output; $\left(y_{t}-\hat{y}\right)$ is the output gap. It is easy to show that in this case the only way in which the exchange rate could play a role in the monetary policy rule would be one where changes in $e$ (or, in some models, changes in the nominal exchange rate) affect inflation and/or the output gap. To the extent that the "pass-through" coefficient is different from zero, exchange rate changes will affect actual inflation - that is, $\frac{\partial \pi}{\partial e}>0$. If (some) changes in the real exchange rate reflect situations of misalignment they will affect the output gap. Under these circumstances, the optimal policy will be one that takes into account the way in which exchange rate developments affect the two components of the loss function. What is unclear, however, is whether the exchange rate should have an independent role in the monetary policy rule (8). If the authorities have modeled the economy correctly - and in doing so, have incorporated the effects of $e$ on $\pi_{\text {and }} y$-- there is no need to include an exchange rate term in equation (8). This point has been made forcefully by De Gregorio, Tokman and Valdés (2005) in their discussion of Chile's case. If, however, there is a lagged response of both inflation and output to exchange rate changes, the central bank

\footnotetext{
33 Medina and Valdés (2002) develop a model where the authorities also target the current account. They show that the optimal reaction function is significantly different from the traditional Taylor rules.
} 
may want to preempt their effect by adjusting the policy stance when the exchange rate change occurs, rather than when its effects on $\pi$ and $y$ are manifested.

Whether a pre-emptive strategy is preferred to one where the authorities actually wait until $\pi$ and $y$ begin to reflect the actual effects of a change in $e$ is, in the final analysis, an empirical issue. Moreover, it is a country specific issue; the main characteristics of a particular economy - including the dynamics of inflation, the size of the pass-through coefficient, and of different elasticities - will determine the extent of macroeconomic volatility - that is deviations of inflation and growth from targets and trends - is lower when $h_{0}$ and $h_{1}$ are different from zero.

\section{IV.2 A Selective Review of the Literature}

Most analytical discussions on inflation targeting have implicitly assumed that $h_{0}=h_{1}=0$, without actually inquiring the way in which the incorporation of $e$ into the policy rule will be affect welfare and/or macroeconomic performance. In fact, things go even further: most discussions on IT in the mainstream literature have tended to ignore open economy issues. In the important book The Inflation Targeting Debate edited by Ben Bernanke and Mike Woodford, the index has no entry for "devaluation" or "passthrough", and there is only one entry for "exchange rate." This corresponds to the paper by Jonas and Mishkin (2005) on IT in transition economies. Most of the other papers in the volume - authored by influential economists such as Woodford, Bernanke, and Sims, among others - do not include explicit discussions on exchange rate behavior when dealing with monetary policy issues. There are, however, a few exceptions: in their paper, Cecchetti and Kim (2005) have a section on an open economy, but do not ask formally whether $h_{0}$ and/or $h_{1}$ should be equal to zero. In his contribution to the Bernanke and Woodford volume, Mervyn King briefly notes that although the U.K. experienced a sharp currency appreciation (in excess of 20\%) this had not affected the effectiveness of the IT-based policy. Caballero and Krishnamurthy (2005) develop a model of an open economy where the exchange rate plays an important role during a "sudden stop" episode. In their setting the exchange rate does play an important role in determining optimal monetary policy. 
The seminal book by Mike Woodford, Interest and Prices (2003), which provides firm analytical underpinnings for interest rate-based monetary policy, does not deal explicitly with exchange rates; the index has no entries for "exchange rate(s)," "devaluation," or "pass-through." There is one entry for "open economy," although no open economy model is presented, and the discussions on optimal policy rule do not consider the (potential) role of open economy variables. (To be fair, however, one could interpret the discussion in section 2.1 of Chapter 7, on cost-push shocks, as including shocks stemming from exchange rate depreciation.)

The pioneering book by Bernanke et al (1999) includes interesting discussions on the role played by exchange rates in monetary policy implementation in a number of countries. The discussion of the Canadian case - where a Monetary Conditions Index (MCI) that includes the exchange rate has been used explicitly is particularly interesting. ${ }^{34}$ However, the important chapter on "Design and Implementation," (Chapter 3) does not discuss at the analytical level whether exchange rate considerations should be explicitly incorporated into the policy rule in an inflation targeting setting. In the chapter on Israel, Australia and Spain the authors discuss how Spain and Israel gradually relaxed exchange rate bands when they adopted IT, and they explain that in both of these countries the authorities decided "not to respond to short term exchange rate fluctuations" when making monetary policy decisions (Bernanke et al, 1999, page 205).

Mishkin and Savastano (2001) provide one of the most complete discussions on the issue. These authors convincingly argue that the discussion on macroeconomic stability in Latin America is not related to the selection of the exchange rate regime. The issue is one of creating an institutional framework for conducting monetary policy in a credible way. According to them IT provides such a framework. Mishkin and Savastano develop a model where optimality implies a Taylor rule of the following form:

$$
i_{t}=\pi_{t}+b_{1}\left(\pi-\pi^{*}\right)+b_{2} y_{t}+b_{3} e_{t} .
$$

34 New Zealand also adopted a MCI in the late 1990s. 
$e_{t}$ is the $\log$ of the real exchange rate, expressed as deviations from its equilibrium value. The authors make a very important point:

"[I]n Latin America exchange rate fluctuations are likely to have a bigger effect on aggregate demand and aggregate supply (because the passthrough may be larger)...indicates that the weight of the exchange rate in the modified Taylor-rule, $b_{3}$, may be relatively large. However, this is in no way inconsistent with inflation targeting) (Mishkin and Savastano, 2001, page 534).

Ball (1999), Obstfeld and Rogoff (1995) and Svensson (2000) have argued that adding the exchange rate as an additional variable in equations of the type of (7) will result in more stable macroeconomic outcomes. According to a simulation exercise undertaken by Svensson $(1999,2000)$ the optimal values of the exchange rate coefficients are $h_{0}=-0.45$ and $h_{1}=0.45$. Ball (1999) analysis suggests that macroeconomic instability will be reduced if $h_{0}=-0.37$ and $h_{1}=0.17$. These results, however, are model-specific and they will change for different parameterizations.

In a paper presented at a Central Bank of Chile conference, Taylor (2002) reviewed 19 recent models developed to analyze inflation and monetary issues. Of these, only 5 assumed that the exchange rate affected aggregate demand, and only six assumed that exchange rate changes was a factor in the process of price determination. This illustrates quite starkly the fact that many influential researchers continue to think in terms of closed economy monetary models.

At the end of the road, whether $h_{0}$ and $h_{1}$ should indeed be different from zero is a country-specific empirical question, that should be dealt with by analyzing country specific evidence - both historical and based on simulation exercises. After much reflecting on this subject I find it difficult to disagree with Taylor (2001) when he expresses some skepticism on the general merits of adding the exchange rate into the interest rate equation. This is for, at least, two reasons. First, and as pointed out earlier, in properly specified models, the exchange rate already plays an indirect role through its 
effect on $\pi_{t}$ and $y_{t}$; second, adding the exchange rate (or any other asset price, for that matter) into the Taylor rule is likely to add considerable volatility to monetary policy. This conclusion is similar to that of Mishkin and Schmidt-Hebbel (2001) who provide an extensive discussion on the subject. According to them, when implementing policy, central banks should consider the effects of exchange rate fluctuations on inflation and the output gap, but should not consider an independent role for $e_{t}$. According to them, "targeting on an exchange rate is likely to worsen the performance of monetary policy."

\section{IV.3 What do IT Central Banks Actually Do?}

The discussion presented above clearly indicates that the issue of whether monetary policy should react to the exchange rate is not fully resolved. At the analytical level the answer is likely to be country specific and will depend on the structural characteristics of the country, and the authorities' loss function.

The vast majority of central banks, however, do not openly recognize that they explicitly take into account exchange rate developments when conducting monetary policy. Indeed, if pressed, most IT central bankers would go as far a saying that since exchange rate changes tend to affect inflation, they play a role on monetary policy. However, they would be reluctant to acknowledge that the exchange rate plays a direct role of its own in the monetary policy rule itself. That is, in terms of equation (7), the vast majority of IT central bankers would say that in their policy rules: $h_{0}=h_{1}=0$.

As every student of monetary policy knows, however, in most countries there are divergences between what central banks say they do, and what central banks actually do. In a recent paper, Mohanty and Klau (2005) estimated monetary policy reaction functions (i.e. Taylor rules) for 13 emerging and transition economies, and found out that in eleven of them the coefficient of real exchange rate was significant. ${ }^{35}$ This provides strong indication that, contrary to what they state, most IT central banks do take central bank developments into account when determining their monetary policy stance. In Table 8 I

\footnotetext{
35 Other authors that have estimated central bank reaction functions to analyze whether the exchange rate plays a role include Hamermann (2005).
} 
present a list of the countries with the estimated short and long term coefficients in the estimated Taylor-rule reaction functions. ${ }^{36}$

The case of Chile is particularly interesting. According to Mohanty and Klau (2005) base estimates, Chile's Taylor rule may be expressed as follows (t-statistics in parentheses):

$$
\begin{gathered}
i_{t}=0.32+0.97 \pi_{t}+0.32 y_{t}+0.35 \Delta x r_{t}-0.35 \Delta x r_{t-1}+0.32 i_{t-1}, \\
(0.25)(4.87) \quad(1.25) \quad(2.78) \quad(-2.40)
\end{gathered}
$$

where $\Delta x r$ is the change in the real exchange rate. The data are quarterly and the time period covered is from 1992 to 2002. What is particularly interesting about the Chilean case is that the effect of (real) exchange rate changes on Central Bank policy appears to last only one quarter. Indeed the sum of the coefficients for $\Delta x r_{t}$ and $\Delta x r_{t-1}$ add up to zero.

As the results summarized in Table 8 show, there is a wide range of values for both the short run and long run estimated coefficients of the real exchange rate in these Taylor rule reaction functions. (The short run is defined as the sum of the coefficients of $\Delta x r_{t}$ and $\Delta x r_{t-1}$. The long run is the sum of these two coefficients divided by one minus the coefficient of $y_{t-1 .}$. . Short run coefficients, for example, go from a relatively high 0.79 for Mexico, all the way to zero for Chile; long run coefficients show an even larger dispersion. ${ }^{37}$ In order to understand why in some countries monetary policy appears to have been more susceptible to exchange rate changes than I others, I estimated a number of cross country regressions. The dependent variable is the short run exchange rate coefficient reported in Table 8 . The following controls were used: (a) average inflation 1990-1995; (b) standard deviation of quarterly inflation 1990-1995; (c) standard deviation of the real exchange rate 1990-1995; (d) degree of openness of the economy measured as imports plus exports over GDP; (e) length of period for which the country has had floating rates; and (f) number of years since IT was adopted. The results obtained for these six univariate regressions are presented in Table 9. Since I only have

\footnotetext{
36 The coefficients in Table 7 have positive signs, since in this paper I have considered that a higher exchange rate represents depreciation. In the Mohanty and Klau paper higher rate represents appreciation, and the coefficients are negative.

${ }^{37}$ In the case of long run coefficients, most of the very high values are the result of a very low estimate for the lagged interest rate. This may be biasing the long run estimates.
} 
13 observations no attempt was made at running a multivariate regression with all the regressors. In spite of the fact that the sample is extremely small, the results reported in Table 9 are interesting and suggestive. Countries with history of higher inflation seem to have a higher coefficient for $\Delta x r$ in their Taylor rules. Also, countries that have historically had a more volatile (real) exchange rate seem to attach a higher coefficient to the exchange rate in their monetary rule. When both variables are included in a bi-variate regression their coefficient are still positive and continue to have a relatively high level of significance.

\section{Concluding Remarks}

The exchange rate is one of the most important macroeconomic variables in the emerging and transition countries. It affects inflation, exports, imports and economic activity. For decades the vast majority of emerging countries had rigid exchange rate regimes - either pegs (adjustable or hard) or managed. This, however, has changed during the last few years, when an increasingly large number of countries have adopted flexible exchange rate regimes. This move away from exchange rate rigidity has tended to take place at the same time as many countries have embraced inflation targeting as a way of conducting monetary policy. The conjunction of IT and flexible rates has brought to the center of the discussion a host of new policy issues, including issues related to the role of the exchange rate in monetary policy, volatility and the relationship between exchange rate changes and inflation.

In this paper I have addressed three of this issues: (a) the relationship between the pass-through and the effectiveness of nominal exchange rates in IT regimes; (b) the effects of IT on exchange rate volatility; and (c) the role (or potential role) of exchange rate changes on the monetary rule in IT countries. The main findings from this analysis may be summarized as follows: (1) Countries that have adopted IT have experienced a declined in the pas-through from exchange rate changes to inflation. In many of the countries in the sample this decline in the pass-through has been different from CPI inflation than for PPI inflation. There is no evidence, however, of changes in the degree of effectiveness of the nominal exchange rate as a shock absorber. (2) The adoption of IT monetary policy procedures has not resulted in an increase in (nominal or real) 
exchange rate volatility. However, in three out of five countries the adoption of a floating exchange rate regime increased the degree of volatility of exchange rates. And (3), there is some evidence that IT countries with a history of high an unstable inflation tend to take into account explicitly developments in the nominal exchange rate when conducting monetary policy. 
Figure 1: Chile, Alternative Measures of Real Exchange Rate

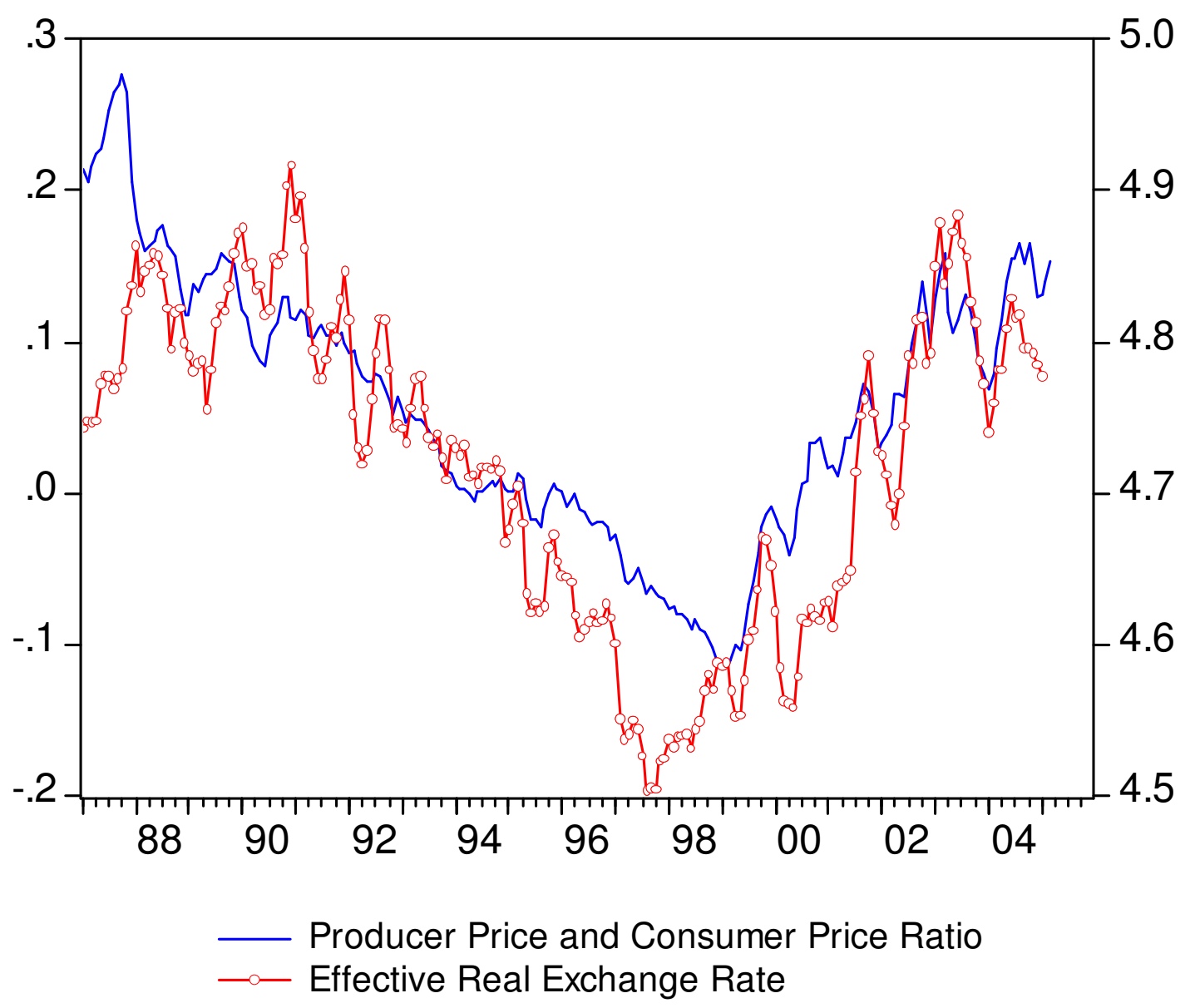


Figure 2: Monthly Nominal Effective Exchange Rate Volatility
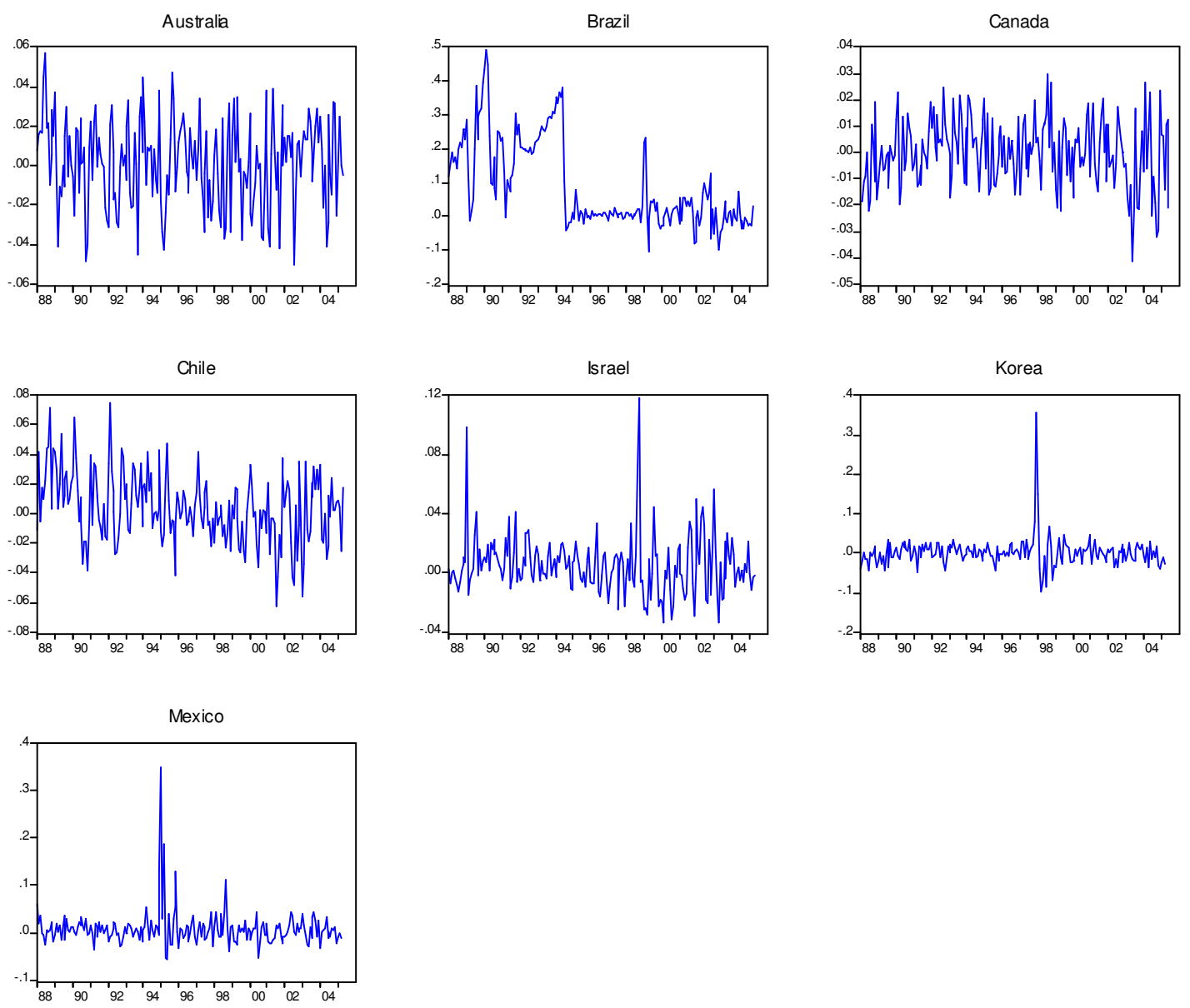
Figure 3: Monthly Changes in Observed and Shadow Nominal Exchange Rate

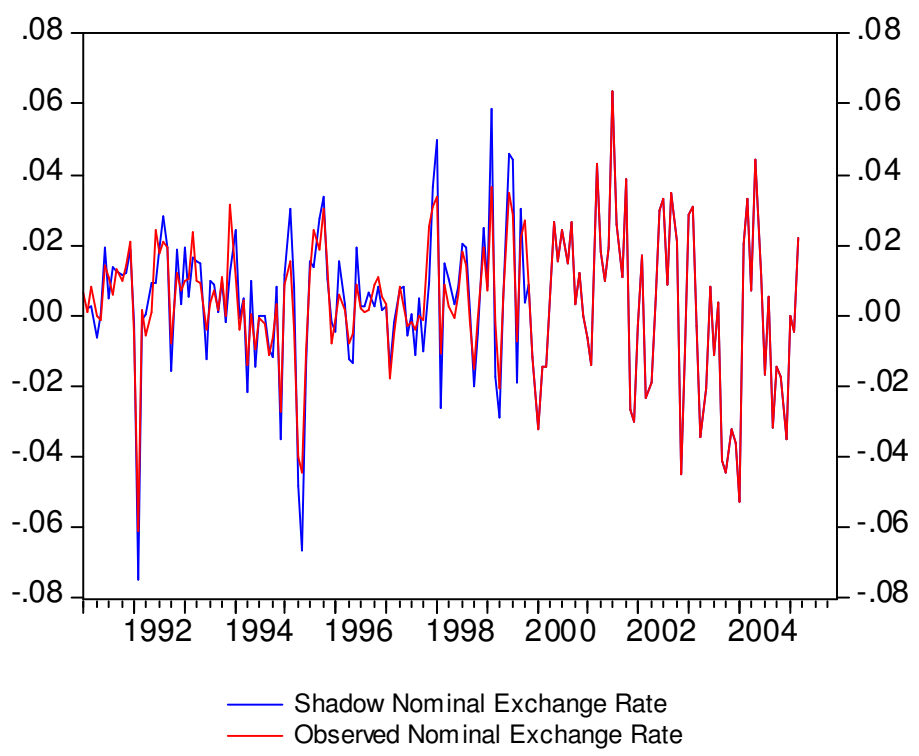


Table 1

Inflation Targeting: Selected Countries

\begin{tabular}{lc}
\hline \hline Country & $\begin{array}{c}\text { Inflation Targeting: } \\
\text { Starting Date }\end{array}$ \\
\hline Australia & Apr-93 \\
Brazil & Jun-99 \\
Canada & Feb-91 \\
Chile & June-91, June-94 \\
Israel & Dec-91 \\
Korea & Jan-98 \\
Mexico & Jan-99 \\
\hline
\end{tabular}

Source: Central Bank's monetary policy reports and press releases;

Various Central Bank of Chile and IMF research papers. 
Table 2

SUR Estimates: Exchange Pass-Through, Selected Countries

(Quarterly Data: 1986.1-2005.1)

\begin{tabular}{|c|c|c|c|c|c|c|c|c|c|c|c|c|c|c|}
\hline & \multicolumn{2}{|c|}{ Australia } & \multicolumn{2}{|c|}{ Brazil } & \multicolumn{2}{|c|}{ Canada } & \multicolumn{2}{|c|}{ Chile } & \multicolumn{2}{|c|}{ Israel } & \multicolumn{2}{|c|}{ Korea } & \multicolumn{2}{|c|}{ Mexico } \\
\hline & $\underline{\mathrm{CPI}}$ & $\underline{\text { PPI }}$ & $\underline{\mathrm{CPI}}$ & $\underline{\text { PPI }}$ & $\underline{\mathrm{CPI}}$ & $\underline{\mathrm{PPI}}$ & $\underline{\mathrm{CPI}}$ & $\underline{\mathrm{PPI}}$ & $\underline{\mathrm{CPI}}$ & $\underline{\text { PPI }}$ & $\underline{\mathrm{CPI}}$ & $\underline{\mathrm{PPI}}$ & $\underline{\mathrm{CPI}}$ & $\underline{\text { PPI }}$ \\
\hline $\operatorname{dlog} E$ & $\begin{array}{l}0.054 \\
(2.34)\end{array}$ & $\begin{array}{l}0.070 \\
(1.31)\end{array}$ & $\begin{array}{l}0.719 \\
(24.76)\end{array}$ & $\begin{array}{c}0.759 \\
(22.30)\end{array}$ & $\begin{array}{l}0.039 \\
(0.79)\end{array}$ & $\begin{array}{l}0.085 \\
(0.79)\end{array}$ & $\begin{array}{l}0.137 \\
(2.88)\end{array}$ & $\begin{array}{l}0.207 \\
(2.08)\end{array}$ & $\begin{array}{l}0.624 \\
(12.18)\end{array}$ & $\begin{array}{l}0.627 \\
(5.95)\end{array}$ & $\begin{array}{l}0.020 \\
(1.20)\end{array}$ & $\begin{array}{l}0.055 \\
(2.10)\end{array}$ & $\begin{array}{l}0.191 \\
(4.85)\end{array}$ & $\begin{array}{l}0.246 \\
(5.98)\end{array}$ \\
\hline $\mathrm{d} \log \mathrm{P}^{*}$ & $\begin{array}{l}0.184 \\
(3.13)\end{array}$ & $\begin{array}{l}0.481 \\
(3.65)\end{array}$ & $\begin{array}{l}0.117 \\
(0.22)\end{array}$ & $\begin{array}{l}0.404 \\
(1.66)\end{array}$ & $\begin{array}{l}0.128 \\
(2.69)\end{array}$ & $\begin{array}{l}0.070 \\
(0.66)\end{array}$ & $\begin{array}{l}0.028 \\
(0.26)\end{array}$ & $\begin{array}{l}0.254 \\
(1.10)\end{array}$ & $\begin{array}{l}0.017 \\
(0.18)\end{array}$ & $\begin{array}{l}0.202 \\
(1.54)\end{array}$ & $\begin{array}{l}0.006 \\
(0.07)\end{array}$ & $\begin{array}{l}0.137 \\
(0.88)\end{array}$ & $\begin{array}{l}0.184 \\
(0.64)\end{array}$ & $\begin{array}{l}0.313 \\
(1.29)\end{array}$ \\
\hline$d \log P_{-1}$ & $\begin{array}{l}0.548 \\
(4.09)\end{array}$ & $\begin{array}{l}0.060 \\
(0.30)\end{array}$ & $\begin{array}{c}0.300 \\
(10.38)\end{array}$ & $\begin{array}{l}0.284 \\
(8.67)\end{array}$ & $\begin{array}{l}0.499 \\
(3.99)\end{array}$ & $\begin{array}{l}0.404 \\
(1.83)\end{array}$ & $\begin{array}{l}0.355 \\
(3.43)\end{array}$ & $\begin{array}{l}0.194 \\
(1.77)\end{array}$ & $\begin{array}{l}0.132 \\
(2.84)\end{array}$ & $\begin{array}{l}0.121 \\
(2.92)\end{array}$ & $\begin{array}{l}0.200 \\
(2.07)\end{array}$ & $\begin{array}{l}0.213 \\
(2.15)\end{array}$ & $\begin{array}{c}0.635 \\
(10.49)\end{array}$ & $\begin{array}{c}0.584 \\
(10.06)\end{array}$ \\
\hline $\mathrm{C}$ & $\begin{array}{l}0.006 \\
(2.27)\end{array}$ & $\begin{array}{l}0.011 \\
(2.51)\end{array}$ & $\begin{array}{l}0.011 \\
(0.55)\end{array}$ & $\begin{array}{c}-0.013 \\
(0.54)\end{array}$ & $\begin{array}{l}0.004 \\
(2.75)\end{array}$ & $\begin{array}{l}0.003 \\
(1.24)\end{array}$ & $\begin{array}{l}0.003 \\
(3.88)\end{array}$ & $\begin{array}{l}0.016 \\
(1.66)\end{array}$ & $\begin{array}{l}0.024 \\
(4.78)\end{array}$ & $\begin{array}{l}0.018 \\
(4.33)\end{array}$ & $\begin{array}{l}0.013 \\
(4.59)\end{array}$ & $\begin{array}{l}0.003 \\
(0.94)\end{array}$ & $\begin{array}{l}0.026 \\
(1.96)\end{array}$ & $\begin{array}{l}0.021 \\
(1.79)\end{array}$ \\
\hline $\mathrm{DIT}^{*} \mathrm{~d} \log \mathrm{E}$ & $\begin{array}{c}-0.057 \\
(1.55)\end{array}$ & $\begin{array}{c}-0.054 \\
(0.60)\end{array}$ & $\begin{array}{c}-0.663 \\
(4.95)\end{array}$ & $\begin{array}{c}-0.524 \\
(3.28)\end{array}$ & $\begin{array}{c}-0.066 \\
(1.20)\end{array}$ & $\begin{array}{l}0.032 \\
(0.28)\end{array}$ & $\begin{array}{c}-0.132 \\
(2.27)\end{array}$ & $\begin{array}{c}-0.162 \\
(1.32)\end{array}$ & $\begin{array}{c}-0.427 \\
(5.23)\end{array}$ & $\begin{array}{c}-0.430 \\
(6.42)\end{array}$ & $\begin{array}{c}-0.031 \\
(0.43)\end{array}$ & $\begin{array}{c}-0.063 \\
(0.77)\end{array}$ & $\begin{array}{c}-0.176 \\
(1.05)\end{array}$ & $\begin{array}{c}-0.053 \\
(0.31)\end{array}$ \\
\hline $\mathrm{DIT}^{*} \mathrm{~d} \log \mathrm{P}_{-1}$ & $\begin{array}{c}-0.344 \\
(1.76)\end{array}$ & $\begin{array}{c}-0.011 \\
(0.05)\end{array}$ & $\begin{array}{l}0.866 \\
(1.51)\end{array}$ & $\begin{array}{l}0.379 \\
(1.41)\end{array}$ & $\begin{array}{c}-0.488 \\
(2.77)\end{array}$ & $\begin{array}{c}-0.054 \\
(0.19)\end{array}$ & $\begin{array}{c}-0.090 \\
(0.79)\end{array}$ & $\begin{array}{c}-0.120 \\
(0.66)\end{array}$ & $\begin{array}{l}0.120 \\
(0.92)\end{array}$ & $\begin{array}{c}-0.064 \\
(0.54)\end{array}$ & $\begin{array}{c}-0.097 \\
(0.43)\end{array}$ & $\begin{array}{c}-0.039 \\
(0.51)\end{array}$ & $\begin{array}{l}-0.454 \\
(2.02)\end{array}$ & $\begin{array}{c}-0.362 \\
(1.74)\end{array}$ \\
\hline $\mathrm{R}^{2}$ & 0.467 & 0.234 & 0.974 & 0.964 & 0.349 & 0.220 & 0.667 & 0.169 & 0.866 & 0.880 & 0.210 & 0.110 & 0.793 & 0.790 \\
\hline $\begin{array}{l}\text { Durbin- } \\
\text { Watson. }\end{array}$ & 2.11 & 2.17 & 2.39 & 2.41 & 2.14 & 2.06 & 2.13 & 1.74 & 2.46 & 2.10 & 2.15 & 2.32 & 2.31 & 2.37 \\
\hline $\begin{array}{l}\text { Determinant } \\
\text { residual } \\
\text { covariance }\end{array}$ & - & $4.85 \mathrm{e}-9$ & - & $4.13 e-6$ & - & $1.49 \mathrm{e}-9$ & - & $3.73 \mathrm{e}-8$ & - & $2.98 \mathrm{e}-8$ & - & $7.19 \mathrm{e}-9$ & - & $5.23 \mathrm{e}-8$ \\
\hline Time period & $\begin{array}{c}86.1- \\
05.1 \\
\end{array}$ & $\begin{array}{c}86.1- \\
05.1 \\
\end{array}$ & $\begin{array}{c}86.1- \\
05.1 \\
\end{array}$ & $\begin{array}{c}86.1- \\
05.1 \\
\end{array}$ & $\begin{array}{c}86.1- \\
05.1 \\
\end{array}$ & $\begin{array}{c}86.1- \\
05.1 \\
\end{array}$ & $\begin{array}{c}88.1- \\
05.1 \\
\end{array}$ & $\begin{array}{c}88.1- \\
05.1 \\
\end{array}$ & $\begin{array}{c}86.1- \\
05.1 \\
\end{array}$ & $\begin{array}{c}86.1- \\
05.1 \\
\end{array}$ & $\begin{array}{c}86.1- \\
05.1 \\
\end{array}$ & $\begin{array}{c}86.1- \\
05.1 \\
\end{array}$ & $\begin{array}{c}86.1- \\
05.1 \\
\end{array}$ & $\begin{array}{c}86.1- \\
05.1 \\
\end{array}$ \\
\hline
\end{tabular}

$\mathrm{E}$ is nominal effective exchange rate, $\mathrm{P} *$ is the US producer price index, $\mathrm{P}_{-1}$ is one lag of domestic producer or consumer price index, and DIT is dummy for periods with inflation targeting. 
Table 3

Short-Run and Long-Run Exchange Pass-Through, Selected Countries

(Quarterly Data: 1986.1-2005.1)

\begin{tabular}{|c|c|c|c|c|c|c|c|c|}
\hline & \multicolumn{4}{|c|}{ CPI Equations } & \multicolumn{4}{|c|}{ PPI Equations } \\
\hline & \multicolumn{2}{|c|}{ Short-run pass thorough } & \multicolumn{2}{|c|}{ Long-run pass thorough } & \multicolumn{2}{|c|}{ Short-run pass thorough } & \multicolumn{2}{|c|}{ Long-run pass thorough } \\
\hline & $\underline{\text { Pre-IT }}$ & $\underline{\text { Post-IT }}$ & $\underline{\text { Pre-IT }}$ & $\underline{\text { Post-IT }}$ & $\underline{\text { Pre-IT }}$ & $\underline{\text { Post-IT }}$ & $\underline{\text { Pre-IT }}$ & $\underline{\text { Post-IT }}$ \\
\hline Australia & 0.054 & 0.000 & 0.120 & 0.000 & 0.070 & 0.070 & 0.070 & 0.070 \\
\hline Brazil & 0.719 & 0.056 & 1.027 & $-{ }^{b}$ & 0.759 & 0.235 & 1.060 & 0.697 \\
\hline Canada & $0.039^{\mathrm{a}}$ & 0.000 & $0.078^{\mathrm{a}}$ & 0.000 & $0.085^{\mathrm{a}}$ & $0.085^{\mathrm{a}}$ & $0.143^{\mathrm{a}}$ & $0.143^{\mathrm{a}}$ \\
\hline Chile & 0.137 & 0.005 & 0.212 & 0.008 & 0.207 & 0.045 & 0.257 & 0.056 \\
\hline Israel & 0.624 & 0.197 & 0.718 & $-b$ & 0.627 & 0.197 & 0.713 & 0.224 \\
\hline Korea & 0.020 & 0.020 & 0.025 & 0.025 & 0.055 & 0.055 & 0.070 & 0.070 \\
\hline Mexico & 0.191 & 0.015 & 0.523 & 0.018 & 0.246 & 0.246 & 0.591 & 0.316 \\
\hline
\end{tabular}

Source: Author's elaboration based on estimations reported in Table 2. 
Table 4

Wald Tests for Cross Equation Restrictions

$\left(\chi^{2}\right.$ with one degree of freedom $)$

\begin{tabular}{l|cccc}
\hline \hline \multirow{2}{*}{ Australia } & \multicolumn{2}{|c}{ Short-Run } & \multicolumn{2}{c}{ Long-Run } \\
& $\underline{\text { Pre-IT }}$ & $\underline{\text { Post-IT }}$ & $\underline{\text { Pre-IT }}$ & $\underline{\text { Post-IT }}$ \\
\hline \multirow{4}{*}{ Brazil } & 0.078 & 0.131 & 0.209 & 0.132 \\
& $(0.78)$ & $(0.72)$ & $(0.65)$ & $(0.72)$ \\
Canada & $4.240^{*}$ & $3.966^{*}$ & $6.216^{*}$ & 0.543 \\
& $(0.04)$ & $(0.04)$ & $(0.01)$ & $(0.46)$ \\
Chile & 0.189 & $11.189^{* *}$ & 0.085 & $8.219^{*}$ \\
& $(0.66)$ & $(0.01)$ & $(0.77)$ & $(0.00)$ \\
Israel & 0.721 & 0.251 & 0.140 & 0.214 \\
& $(0.39)$ & $(0.61)$ & $(0.71)$ & $(0.64)$ \\
Korea & 0.007 & 0.010 & 0.025 & 0.523 \\
& $(0.93)$ & $(0.87)$ & $(0.87)$ & $(0.46)$ \\
Mexico & $3.466^{* *}$ & 0.030 & $2.840^{* *}$ & 0.051 \\
& $(0.05)$ & $(0.91)$ & $(0.09)$ & $(0.92)$ \\
& $23.523^{*}$ & $14.846^{*}$ & $3.824^{*}$ & $6.235^{*}$ \\
\hline
\end{tabular}

p-values in parenthesis

* significant at $5 \%$ level

** significant at $10 \%$ level 
Table 5

3SLS Estimates: Exchange Pass-Through, Chile

(Quarterly Data: 1988.1-2005.2)

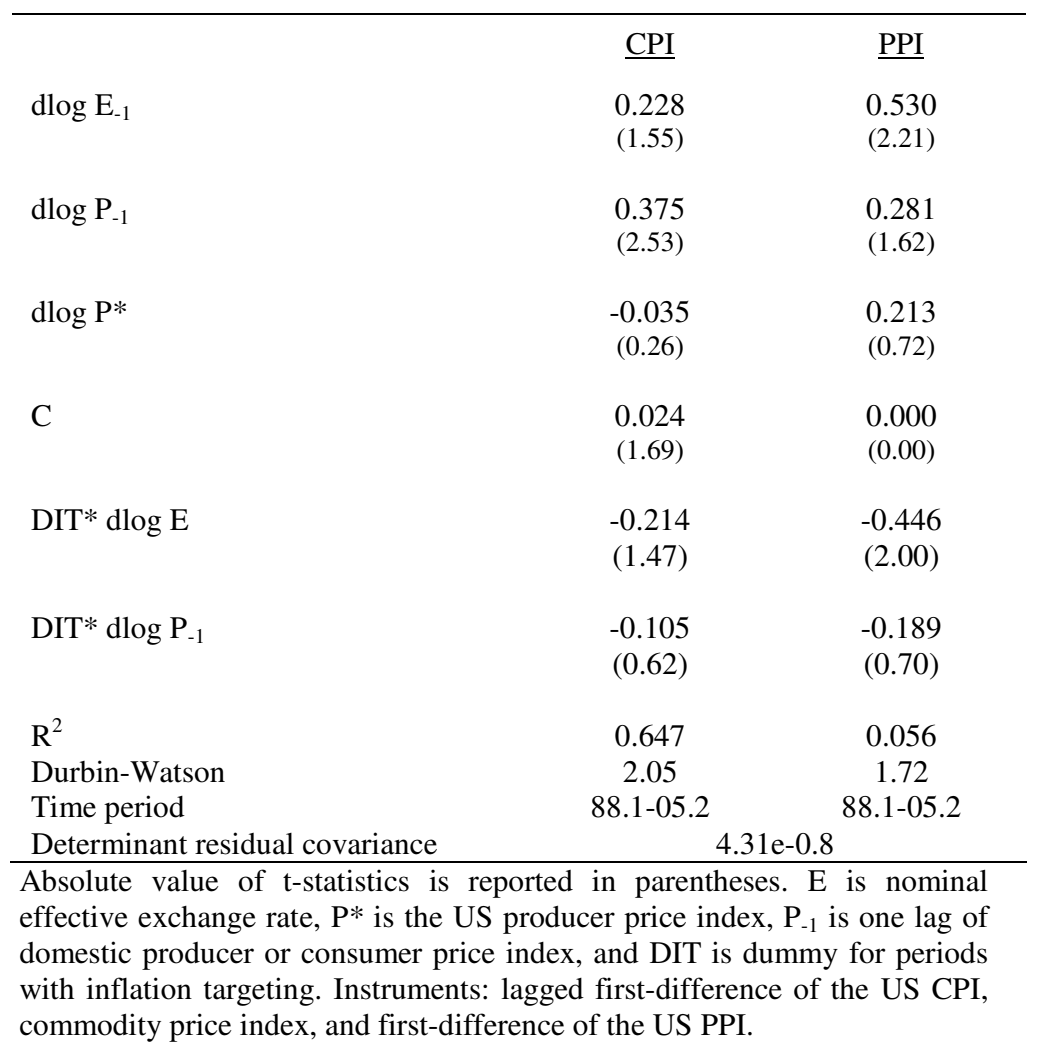


$\underline{\text { Table } 6}$

GARCH Estimates: Inflation Targeting, Exchange Rate Regime, and Nominal Exchange Rate Volatility, Selected Countries

(Monthly Data: 1988.1-2005.1)

\begin{tabular}{|c|c|c|c|c|}
\hline Country & DIT & Float & $D W$ & $R^{2}$ \\
\hline \multirow[t]{2}{*}{ Australia $(1,1)$} & $6.36 \mathrm{e}-06$ & - & 1.96 & 0.10 \\
\hline & $(0.96)$ & - & & \\
\hline \multirow[t]{2}{*}{ Brazil $(2,2)$} & -0.001 & 0.0008 & 1.97 & 0.25 \\
\hline & (4.16) & $(2.55)$ & & \\
\hline \multirow[t]{2}{*}{ Canada $(1,1)$} & $6.73 \mathrm{e}-06$ & - & 1.89 & 0.04 \\
\hline & $(0.66)$ & - & & \\
\hline \multirow[t]{2}{*}{ Chile $(1,1)^{\mathrm{a}}$} & $-7.48 \mathrm{e}-06$ & $1.71 \mathrm{e}-07$ & 1.96 & 0.18 \\
\hline & (1.70) & (3.57) & & \\
\hline \multirow[t]{2}{*}{ Chile $(1,1)^{\mathrm{b}}$} & $-1.57 \mathrm{e}-05$ & $2.54 \mathrm{e}-05$ & 1.94 & 0.22 \\
\hline & $(4.20)$ & $(5.97)$ & & \\
\hline \multirow[t]{2}{*}{ Israel $(1,1)$} & $-3.71 e-04$ & $3.94 \mathrm{e}-04$ & 2.30 & 0.05 \\
\hline & $(5.44)$ & $(3.92)$ & & \\
\hline \multirow[t]{2}{*}{ Korea $(1,0)$} & 0.002 & 0.002 & 1.73 & 0.10 \\
\hline & $(0.94)$ & $(0.95)$ & & \\
\hline \multirow[t]{2}{*}{ Mexico $(1,1)$} & $-3.67 e-04$ & $2.1 \mathrm{e}-04$ & 2.50 & 0.14 \\
\hline & $(1.06)$ & $(0.63)$ & & \\
\hline
\end{tabular}

Absolute value of z-statistics are reported in parentheses. DIT is a dummy for periods with inflation targeting, and Float is a dummy for periods with floating exchange rate.

${ }^{\text {a }}$ Inflation targeting assumed to start on June, 1991.

${ }^{\mathrm{b}}$ Inflation targeting assumed to start on June, 1994. 
$\underline{\text { Table } 7}$

GARCH Estimates: Inflation Targeting, Exchange Rate Regime, and Real Exchange

Rate Volatility, Selected Countries

(Monthly Data: 1988.1-2005.1)

\begin{tabular}{l|cccccc}
\hline \hline Country & Mean Equation & GARCH & DIT & Float & DW & $R^{2}$ \\
\hline \multirow{2}{*}{ Australia } & AR(2) & $(1,1)$ & $-1.77 \mathrm{e}-06$ & - & 1.96 & 0.07 \\
& & & $(0.52)$ & - & & \\
Canada & AR(3) & $(1,3)$ & $-3.67 \mathrm{e}-05$ & - & 2.03 & 0.04 \\
& & & $(1.11)$ & - & & \\
Chile $^{\mathrm{a}}$ & $\mathrm{AR}(1)$ & $(2,2)$ & $-8.39 \mathrm{e}-06$ & $2.50 \mathrm{e}-06$ & 1.87 & 0.05 \\
& & & $(1.27)$ & $(4.02)$ & & \\
Chile $^{\mathrm{b}}$ & $\mathrm{AR}(1)$ & $(2,2)$ & $-2.35 \mathrm{e}-05$ & $4.66 \mathrm{e}-05$ & 1.89 & 0.10 \\
& & & $(2.57)$ & $(4.22)$ & & \\
Israel & $\mathrm{AR}(1)$ & $(2,2)$ & $-3.47 \mathrm{e}-05$ & $7.05 \mathrm{e}-05$ & 1.89 & 0.09 \\
& & & $(1.43)$ & $(1.75)$ & & \\
\hline
\end{tabular}

Absolute value of z-statistics is reported in parentheses. DIT is a dummy for periods with inflation targeting, and Float is a dummy for periods with floating exchange rate.

${ }^{a}$ Inflation targeting assumed to start on June, 1991.

${ }^{\mathrm{b}}$ Inflation targeting assumed to start on June, 1994. 
Table 8

Interest Rate Response to Changes in Real Exchange Rate

(Obtained from estimated Taylor-Rule Equations)

\begin{tabular}{lcc}
\hline \hline Country & Short term & Long term \\
\hline India & 0.18 & 0.60 \\
Korea & 0.29 & 0.67 \\
Philippines & 0.09 & 0.13 \\
Taiwan & 0.03 & 0.18 \\
Thailand & 0.31 & 0.74 \\
Brazil & 0.10 & 0.36 \\
Chile & 0.00 & 0.00 \\
Mexico & 0.79 & 1.58 \\
Peru & 0.38 & 2.71 \\
Czech Republic & -0.03 & -0.19 \\
Hungary & 0.15 & 0.60 \\
Poland & 0.05 & 0.20 \\
South Africa & 0.12 & 6.00 \\
\hline Souce: Maly
\end{tabular}

Source: Mohanty and Klau (2005) 
Table 9

Exchange Rate Coefficient in Taylor-Rule Equations and Country Characteristics $\underline{\text { (Ordinary Least Squares) }}$

\begin{tabular}{|c|c|c|c|c|c|c|}
\hline & (1) & (2) & (3) & (4) & (5) & (6) \\
\hline Average Inflation & $\begin{array}{c}0.015 \\
(1.74)^{* * *}\end{array}$ & & & & & \\
\hline St. Dev. Inflation & & $\begin{array}{l}0.010 \\
(0.71)\end{array}$ & & & & \\
\hline St. Dev. Real Exchange Rate & & & $\begin{array}{c}0.040 \\
(1.78)^{* * *}\end{array}$ & & & \\
\hline Trade Openness & & & & $\begin{array}{l}-0.001 \\
(0.64)\end{array}$ & & \\
\hline Length period with floating regime & & & & & $\begin{array}{l}-0.000 \\
(0.11)\end{array}$ & \\
\hline Years since IT was adopted & & & & & & $\begin{array}{l}0.005 \\
(0.26)\end{array}$ \\
\hline Constant & $\begin{array}{l}0.037 \\
(0.35)\end{array}$ & $\begin{array}{l}0.140 \\
(1.51)\end{array}$ & $\begin{array}{l}-0.031 \\
(0.23)\end{array}$ & $\begin{array}{l}0.276 \\
(1.86)\end{array}$ & $\begin{array}{l}0.207 \\
(1.17)\end{array}$ & $\begin{array}{l}0.170 \\
(1.73)\end{array}$ \\
\hline Observations & 13 & 13 & 13 & 13 & 13 & 13 \\
\hline R-squared & 0.22 & 0.04 & 0.22 & 0.04 & 0.00 & 0.01 \\
\hline
\end{tabular}

Absolute value of $\mathrm{t}$ statistics in parentheses

$* * *$ significant at $10 \%$; ** significant at $5 \%$, $*$ significant at $1 \%$ 


\section{REFERENCES}

Atkeson, Andrew and Ariel Burstein. 2005. "Trade Costs, Pricing to Market, and International Relative Prices," mimeo, University of California at Los Angeles.

Ball, Laurence. 1999. "Policy Rules for Open Economies," In J. Taylor (ed.): Monetary Policy Rules, Chicago: University of Chicago Press.

Bernanke, Ben S. 2004. "Central Bank Talk and Monetary Policy," speech before the Japan Society, New York, New York, October 7. http://www.federalreserve.gov/boarddocs/speeches/2004/200410072/default.htm

Bernanke, Ben S. and Michael Woodford. 2005. The Inflation-Targeting Debate, NBER Studies in Business Cycles, vol. 32. Chicago and London: University of Chicago Press.

Bernanke, Ben S., Laubach, Thomas, Mishkin, Frederic S., and Adam S. Posen. 1999. Inflation Targeting: Lessons from the International Experience, Princeton, Princeton University Press.

Borensztein, Eduardo and, José De Gregorio. 1999. "Devaluation and Inflation after Currency Crises," Unpublished manuscript, Universidad de Chile, February.

Caballero, Ricardo J. and Arvind Krishnamurthy. 2005. "Inflation Targeting and Sudden Stops," in Bernanke, Ben S. and Michael Woodford (eds.): The Inflation-Targeting Debate, NBER Studies in Business Cycles, vol. 32. Chicago and London: University of Chicago Press.

Calvo, Guillermo A. 1999. "Fixed vs. Flexible Exchange Rates" Fixed vs. Flexible Exchange Rates: Preliminaries of a Turn-of-Millennium Rematch," mimeo, University of Maryland.

Calvo, Guilermo A. and Carmen Reinhart, 2002, "Fear of Floating," Quarterly Journal of Economics, 117(2): 379-408.

Campa, Jose Manuel and Linda S. Goldberg. 2002. "Exchange Rate Pass-Through into Import Prices: A Macro or Micro Phenomenon?," NBER WP 8934, May.

Cecchetti Stephen G. and Junhan Kim. 2005. "Inflation Targeting, Price-Path Targeting, and Output Variability," in Bernanke, Ben S. and Michael Woodford (eds.): The Inflation-Targeting Debate, NBER Studies in Business Cycles, vol. 32. Chicago and London: University of Chicago Press.

Corbo, Vittorio. 1998. "Reaching One-Digit Inflation: The Chilean Experience," Journal of Applied Economics. 1(1): 123-63. 
Corbo, Vittorio and Klaus Schmidt-Hebbel. 2003. "Inflation Targeting: The Latin American Experience," in Gonzalez, Jose Antonio, et. al. (eds): Latin American Macroeconomic Reforms: The Second Stage. Chicago and London: University of Chicago Press: 19-71.

Della Paolera, Gerardo and Alan M. Taylor. 2003. New Economic History of Argentina, Cambridge: Cambridge University Press, 2003

De Gregorio, José and Andrea Tokman. 2004. "Flexible Exchange Rate Regime and Forex Interventions: The Chilean Case," Economic Policy Papers $\mathrm{N}^{\circ} 11$, Central Bank of Chile, December.

De Gregorio, José, Tokman, Andrea, and Rodrigo Valdés. 2005. "Tipo de Cambio Flexible con Metas de Inflación en Chile: Experiencia y Temas de Interés,". Documento de Política Económica N¹4. Banco Central de Chile. Agosto.

Diaz-Alejandro, Carlos F. 1970. Essays on the Economic History of the Argentine Republic, New Haven, Conn.: Yale University Press.

Domínguez, Kathryn and Jeffrey A. Frankel. 1993. "Does Foreign-Exchange Intervention Matter?. The Portfolio Effect”. American Economic Review, 83(5): 1356-69.

Edwards, Sebastian. 1998. “Two Crises: Inflationary Inertia and Credibility”, The Economic Journal, 108 (May): 680-702.

Edwards, Sebastian and Eduardo Levy Yeyati. 2005. "Flexible Exchange Rates as Shock Absorbers," European Economic Review, 49(8): 2079-2105

Edwards, Sebastian and Roberto Rigobon. 2005. "Capital Controls, Exchange Rate Volatility and External Vulnerability," NBER Working Paper No. 11434.

Gagnon, Joseph E. and Jane Ihrig. 2004. "Monetary Policy and Exchange Rate PassThrough," International Journal of Finance and Economics, 9(4): 315-338.

Hammermann, Felix. 2005. "Do Exchange Rates Matter in Inflation Targeting Regimes? Evidence from a VAR Analysis for Poland and Chile," in Langhammer, R. J. and L. Vinhas de Souza, (Eds.): Monetary Policy and Macroeconomic Stabilization in Latin America.

Hochreiter, Eduard and Pierre L. Siklos, 2002. "Alternative Exchange-Rate Regimes: The Options for Latin America," The North American Journal of Economics and Finance, 13(3): 195-211. 
Jonas, Jiri and Frederic S. Mishkin. 2005. "Inflation Targeting in Transition Countries: Experience and Prospects," in Bernanke, Ben S. and Michael Woodford (eds.): The Inflation-Targeting Debate, NBER Studies in Business Cycles, vol. 32. Chicago and London: University of Chicago Press.

Kearns, Jonathan and Roberto Rigobon (2002). "Identifying the Efficacy of Central Bank Interventions: The Australian Case," Journal of International Economics, 66(1): 3148.

Levy-Yeyeti, Eduardo and Federico Sturzenegger. 2003. "To Float or to Fix: Evidence on the Impact of Exchange Rate Regimes on Growth," American Economic Review, 93 (4), pp. 1178-89.

Medina, Juan P. and Rodrigo Valdés. 2002. "Optimal Monetary Policy Rules under Inflation Range Targeting," in Loayza N. and K. Schmidt-Hebbel (eds.): Monetary Policy: Rules and Transmission Mechanisms. Series on Central Banking, Analysis, and Economic Policies, vol. 4. Santiago: Central Bank of Chile, 95-115

Meese, Richard, and Rogoff Kenneth. "Empirical Exchange Rate Models of the Seventies," Journal f International Economics, 14(1-2): 3-24.

Meller, Patricio. 1996. Un Siglo de Economía Política Chilena: 1890-1990. Santiago, Andrés Bello.

Mishkin, Frederic S. and Klaus Schmidt-Hebbel. 2001. "One Decade of Inflation Targeting in the World: What do we Know? What do we Need to Know?," NBER WP 8397, July.

Mishkin, Frederic S. and Miguel A. Savastano. 2001. "Monetary Policy Strategies for Latin America," Journal of Development Economics, 66(2): 415-444.

Mohanty, M.S. and Marc Klau. 2005. "Monetary Policy Rules in Emerging Market Economies: Issues and Evidence," in Langhammer, R. J. and L. Vinhas de Souza, (Eds.): Monetary Policy and Macroeconomic Stabilization in Latin America.

Morandé, Felipe. 2002. “A Decade of Inflation Targeting in Chile. Developments, Lessons, and Challenges", in N. Loayza y R. Soto (eds.): Inflation Targeting: Design, Performance, Challenges, Santiago, Central Bank of Chile: 583-626.

Neely, Christopher J. 2001. "The Practice of Central Bank Intervention: Looking under the Hood". Federal Reserve Bank of St. Louis Review, 83(3): 1-10.

Obstfeld, Maurice and Kenneth Rogoff. 1995. "The Mirage of Fixed Exchange Rates," Journal of Economic Perspectives, 9(4): 73-96.

Pazos, Felipe. 1972. Chronic Inflation in Latin America. New York: Praeger Publishers. 
Reinhart, Carmen M. and Kenneth S. Rogoff. 2004. "The Modern History of Exchange Rate Arrangements: A Reinterpretation," Quarterly Journal of Economics, 119(1): 148.

Sarno, Lucio and Mark P. Taylor. 2001. "Official Intervention in the Foreign Exchange Market: Is It Effective and, If So, How Does It Work?," Journal of Economic Literature, 39(3): 839-68.

Schmidt-Hebbel, Klaus and Alejandro Werner. 2002. "Inflation Targeting in Brazil, Chile, and Mexico: Performance, Credibility, and the Exchange Rate. Economia. 2(2): 31-89.

Schmidt-Hebbel, Klaus; and Matias Tapia. 2002. "Inflation Targeting in Chile," North American Journal of Economics and Finance, 13(2): 125-46.

Svensson, Lars E. O. 1999. "Inflation Targeting as a Monetary Policy Rule," Journal of Monetary Economics 43 (3): 607-654. 2000. "Open-Economy Inflation Targeting," Journal of International Economics, 50(1): 155-183.

Tapia, Matías and Andrea Tokman. 2004. "Effects of Foreign Exchange Intervention under Public Information: The Chilean Case," Central Bank of Chile Working Papers $\mathrm{N}^{\circ} 255$.

Taylor, Mark P. 2004. "Is Official Exchange Rate Intervention Effective?," Economica, 71(281): 1-11.

Taylor, John B. 2000. "Low Inflation, Pass-Through, and the Pricing Power of Firms," European Economic Review, 44 (7): 1389-1408.

2001. The Role of the Exchange Rate in Monetary-Policy Rules," American Economic Review, 91(2): 263-267.

2002. The Monetary Transmission Mechanism and the Evaluation of Monetary Policy Rules," in Loayza N. and K. Schmidt-Hebbel (eds.): Monetary Policy: Rules and Transmission Mechanisms, Series on Central Banking, Analysis, and Economic Policies, vol. 4. Santiago: Central Bank of Chile.

Woodford, Mike. 2003. Interest and Prices, Princeton and Oxford: Princeton University Press. 